\title{
PENGARUH STATUS GIZI DAN STATUS ANEMIA TERHADAP DAYA INGAT SESAAT SISWA DI SDN PASANGGRAHAN 1 KABUPATEN PURWAKARTA
}

\author{
(Effect of nutritional status and anemia status on short term memory of children at Elementary \\ School of Pasanggrahan 1, District of Purwakarta)
}

\author{
Junaida Astina ${ }^{1 *}$ dan Ikeu Tanziha ${ }^{1}$ \\ ${ }^{1}$ Departemen Gizi Masyarakat, Fakultas Ekologi Manusia (FEMA), Institut Pertanian Bogor, \\ Jl. Raya Darmaga, Bogor 16880
}

\begin{abstract}
The objective of this study was to analyze the relationship between nutritional status and anemia status on short term memory among Elementary School Children of SDN Pasanggrahan 1, District of Purwakarta. Crosssectional study design was used in this study. Fifty children from this elementary school were selected by purposive sampling, but only thirty nine children that fulfilled the requirements. Short term memory tests used in this study were done by giving several words to be learned by children and then retrieved. Pearson and Spearman correlation was used to analyze correlation between social economic, anemia and nutritional status with short term memory. Linear regression was used to analyze effects of children characteristics, physical activity, consumption, anemia and nutritional status on short term memory. The result showed that average score of short term memory in the morning was higher than score in the afternoon. Nutritional status had positive correlation with short term memory score in the afternoon $(p<0.1)$ and nutritional knowledge had positive correlation with short term memory score in the morning and afternoon $(p<0.1)$. Short term memory were effected by nutritional knowledge, nutritional, and anemia status.
\end{abstract}

Key words: anemia, nutritional status, school-aged children, short term memory

\begin{abstract}
ABSTRAK
Penelitian ini bertujuan untuk menganalisis hubungan antara status gizi dan status anemia dengan daya ingat sesaat siswa di SDN Pasanggrahan 1, Kabupaten Purwakarta. Penelitian ini menggunakan desain crosssectional. Subjek dipilih secara purposive dari 50 siswa, namun setelah dilakukan cleaning data, hanya 39 siswa yang termasuk dalam penelitian ini. Uji daya ingat yang digunakan yaitu dengan memberikan daftar kata-kata untuk dipelajari kemudian meretrieve-nya. Hubungan antara variabel sosial ekonomi, status anemia, dan status gizi dengan daya ingat sesaat dianalisis dengan korelasi Pearson. Regresi linear digunakan untuk menganalisis pengaruh dari karakteristik subjek, aktivitas fisik, asupan gizi, status anemia, dan status gizi terhadap daya ingat sesaat. Hasil penelitian menunjukkan bahwa rata-rata skor daya ingat pada pagi hari lebih tinggi dibandingkan skor daya ingat pada siang hari. Status gizi berhubungan positif dengan daya ingat siang $(p<0.1)$, serta pengetahuan gizi berhubungan positif dengan daya ingat pagi dan siang $(p<0.1)$. Faktorfaktor yang memengaruhi daya ingat sesaat yaitu pengetahuan gizi, status gizi, dan status anemia. Semakin baik skor pengetahuan gizi dan status gizi, maka semakin baik pula skor daya ingat sesaat.
\end{abstract}

Kata kunci: anak usia sekolah, anemia, daya ingat sesaat, status gizi

"Korespondensi: Departemen Gizi Masyarakat, Fakultas Ekologi Manusia (FEMA), Institut Pertanian Bogor, Jl. Raya Darmaga, 16680. Tel: 0251 - 8621363, Fax: 0251 - 8622276. Email: iamjunda18@yahoo.com 


\section{PENDAHULUAN}

Prestasi belajar erat kaitannya dengan kemampuan mengingat. Daya ingat dibagi menjadi dua, yaitu daya ingat jangka pendek (short term memory) dan daya ingat jangka panjang (long term memory). Kemampuan mengingat jangka pendek atau Short Term Memory (STM) digunakan untuk menyimpan informasi baru, yang selanjutnya disimpan dalam Long Term Memory (LTM). Berbagai zat gizi dalam tubuh berperan dalam mendukung fungsi tubuh, baik dalam melakukan aktivitas fisik maupun aktivitas berpikir. Tidak hanya zat gizi makro, zat gizi mikro pun memiliki peran penting bagi otak. Penelitian Morris et al. (2007) pada kelompok lanjut usia di Amerika Serikat menunjukkan bahwa status vitamin B12 yang rendah berkaitan dengan anemia dan penurunan fungsi kognitif walaupun kadar serum folat tergolong tinggi. Sejalan dengan penelitian tersebut, penelitian lain yang dilakukan Mc Gregor SG, Ani C (2001) serta Pollit (2000) menunjukkan bahwa anemia gizi besi pada anak usia dini dapat menurunkan perkembangan kognitif anak. Menurut laporan Riskesdas 2007, prevalensi anemia pada anak di Jawa Barat sebesar $18.8 \%$. Angka prevalensi tersebut melebihi angka prevalensi anemia anak secara nasional sebesar $12.8 \%$. Berbagai zat gizi berperan sebagai faktor pendukung hemoglobin untuk mengangkut oksigen dan zat gizi ke seluruh tubuh, termasuk otak. Jika tubuh kekurangan zat gizi yang berhubungan dengan proses pembentukan sel darah merah, maka pembentukan sel darah merah tidak akan optimal sehingga pasokan oksigen dan zat gizi lain tidak dapat disirkulasikan secara optimal.

Mengingat pentingnya peran status gizi dan status anemia terhadap konsentrasi dan daya ingat anak dalam mendukung proses belajar, maka peneliti tertarik untuk meneliti hubungan status gizi dan status anemia dengan daya ingat sesaat siswa di SD Negeri Pasanggarahan 1, Kecamatan Tegal Waru, Kabupaten Purwakarta.

Tujuan umum penelitian ini adalah menganalisis hubungan antara status gizi dan status anemia dengan daya ingat sesaat siswa di SDN Pasanggrahan 1, Desa Pasanggrahan, Kecamatan Tegal Waru, Kabupaten Purwakarta.

\section{METODE}

\section{Desain, Tempat, dan Waktu}

Penelitian ini merupakan bagian dari penelitian Tanziha dan Prasojo (2012) berjudul Pemberian Program Pemberian Makanan Tambahan Anak Sekolah (PMT AS) dalam upaya perbaikan status gizi dan kesehatan siswa, kerjasama LSM Nurani Dunia, IPB, dan Badan Amil Zakat Nasional (BAZNAS). Penelitian ini menggunakan desain Cross-Sectional, bertempat di SDN Pasanggrahan 1, Desa Pasanggrahan, Kecamatan Tegal Waru, Kabupaten Purwakarta. Penelitian dilakukan dari bulan Januari 2012 sampai Maret 2012.

\section{Jumlah dan Cara Penarikan Subjek}

Teknik pengambilan subjek yang digunakan adalah purposive sampling. Subjek yang diambil dalam penelitian ini adalah siswa sekolah dasar kelas 4 dan 5 di SDN Pasanggrahan 1. Pertimbangan diambilnya subjek kelas 4 dan 5 karena sudah mulai kooperatif dan tidak sedang dalam persiapan ujian. Total subjek dalam penelitian ini adalah 50 anak, dengan masing-masing 25 anak laki-laki dan 25 anak perempuan. Kriteria inklusi dalam pengambilan subjek adalah siswa siswi kelas 4 dan 5 SDN Pasanggrahan 1 serta bersedia dan mampu mengikuti penelitian dari awal hingga akhir. Namun karena 11 orang tidak melengkapi data yang dibutuhkan dalam penelitian ini, total subjek yang terlibat dalam penelitian ini adalah 39 siswa.

\section{Jenis dan Cara Pengumpulan Data}

Data yang dikumpulkan dalam penelitian ini adalah data primer dan data sekunder. Data primer meliputi data karakteristik keluarga siswa, karakteristik siswa, antropometri, pengetahuan gizi, konsumsi pangan, aktivitas fisik, kadar $\mathrm{Hb}$, dan daya ingat sesaat siswa. Karakteristik keluarga didapat berdasarkan hasil wawancara dengan orang tua siswa, meliputi pendidikan orang tua, besar keluarga, dan pendapatan per kapita. Data karakteristik siswa (jenis kelamin dan usia), pengetahuan gizi, aktivitas fisik, serta konsumsi pangan dan kebiasaan jajan diperoleh berdasarkan wawancara kepada siswa menggunakan kuesioner. Berat badan siswa diukur menggunakan timbangan injak dengan ketelitian $0.1 \mathrm{~kg}$ sedangkan tinggi badan siswa diukur menggunakan microtoise dengan ketelitian $0.1 \mathrm{~cm}$. Data konsumsi pangan didapatkan dengan metode recall $2 \times 24$ jam. Kadar $\mathrm{Hb}$ diukur dengan metode HemoCue ${ }$.

Pengukuran daya ingat sesaat dilakukan selama dua hari berturut-turut menggunakan daftar kata yang umum digunakan (Kustiyah 2006). Daftar kata yang dibuat terdiri atas enam buah kata yang disusun secara acak. Kata-kata tersebut dituliskan pada suatu karton berwarna putih dengan huruf Times New Roman ukuran 200 point berwarna hitam. Topik kata yang digunakan meliputi nama ne- 
gara, nama bunga, nama makanan jajanan yang ada di sekolah subjek, hubungan kekerabatan, jenis hewan, dan nama buah. Kata yang diujikan pada hari pertama yaitu mangga, kucing, melati, Indonesia, cilok, dan ibu. Kata yang diujikan pada hari kedua yaitu adik, kamboja, ayam, batagor, jambu, dan India. Kata-kata yang diujikan tersebut telah diujicobakan terlebih dahulu kepada siswa seminggu sebelumnya untuk memvalidasi bahwa kata-kata tersebut dapat diingat secara spontan dan dapat diujikan dalam penelitian daya ingat sesaat. Pada saat pengujian, siswa diberikan waktu selama sembilan detik untuk menghafalkan enam buah kata tersebut. Saat menghafalkan kata, siswa tidak diperkenankan untuk memegang alat tulis apapun. Selanjutnya siswa diberikan waktu selama dua puluh lima detik untuk menulis kembali kata yang diingat. Pengukuran daya ingat sesaat dilakukan pada dua waktu, yaitu pada jam 09.00 WIB dan 11.00 WIB.

Data sekunder yang dikumpulkan meliputi data nama, jenis kelamin, dan tanggal lahir siswa serta data nama dan pekerjaan orang tua. Data tersebut didapatkan dari kantor administrasi sekolah.

\section{Pengolahan dan Analisis Data}

Pengolahan data dilakukan dengan cara pengkodean (coding), pemasukan data (entry), pengecekan ulang (cleaning), dan analisis data. Data diolah dengan Microsoft Excel 2007 serta dianalisis menggunakan Statistical Program for Social Science (SPSS) 16.0 for Windows. Data berat badan, tinggi badan, dan usia diolah untuk mendapatkan data status gizi dengan software WHO Anthroplus. Status gizi dibedakan menjadi lima kategori berdasarkan z-score IMT/U menurut WHO 2007, yaitu obes, overweight, normal, kurus, dan sangat kurus. Selain status gizi, dilakukan juga pengolahan data kadar $\mathrm{Hb}$ untuk mengetahui status anemia subjek. Data $\mathrm{Hb}$ yang diperoleh dikategorikan dalam dua kelompok berdasarkan WHO 2007, yaitu normal dan anemia. Dikategorikan normal yaitu jika kadar $\mathrm{Hb} \geq 11 \mathrm{~g} /$ $\mathrm{dL}$ dan anemia jika kadar $\mathrm{Hb}<11 \mathrm{~g} / \mathrm{dL}$. Karakteristik keluarga mencakup besar keluarga, pendidikan orang tua, pekerjaan orang tua, dan pendapatan per kapita. Pendidikan orang tua dikelompokkan berdasarkan pendidikan terakhir orang tua, yaitu tidak sekolah, SD, SMP, SMA, dan Perguruan Tinggi. Pekerjaan orang tua dikelompokkan menjadi tidak bekerja, petani, petani ikan, buruh, wirausaha, dagang, guru, PNS, polisi, karyawan swasta, dan lainnya (ojek, sopir, dan sebagainya). Pendapatan perkapita dikelompokkan berdasarkan garis kemiskinan Jawa Barat untuk daerah desa per September 2011, yaitu Rp 209 777/kap/bulan. Pendapatan per kapita dikategorikan miskin apabila kurang dari Rp 209 777, dan tidak miskin apabila lebih dari Rp 209777.
Besar keluarga adalah keseluruhan jumlah anggota keluarga yang terdiri dari suami, isteri, anak, dan anggota keluarga lainnya yang tinggal bersama. Besar keluarga dikelompokkan menjadi tiga, yaitu keluarga kecil, jika jumlah anggota keluarga kurang dari empat orang, keluarga sedang, jika jumlah anggota keluarga lima hingga tujuh orang, dan keluarga besar jika jumlah anggota keluarga lebih dari tujuh orang.

Pengetahuan gizi dinilai berdasarkan pertanyaan tentang gizi seimbang dan keamanan makanan jajanan. Jawaban atas pertanyaan gizi tersebut kemudian diberi skor 0 bila salah dan 1 bila benar, kemudian skor dijumlah dan dihitung persentase jawaban yang benar secara keseluruhan. Pengetahuan gizi dikategorikan baik apabila persentase skor benar lebih dari 80\%, sedang apabila persentase skor benar 60-80\%, dan kurang apabila persentase skor benar kurang dari 60\% (Khomsan 2000).

Data konsumsi pangan dengan metode Semi Quantitative Food Frequency Questionnaire (SQFFQ) 2x24 jam diolah menggunakan program Nutrisurvey 2007 untuk mengetahui kebiasaan konsumsi pangan, kebiasaan jajan, serta jumlah asupan zat gizi. Kebiasaan konsumsi pangan dan kebiasaan jajan dikategorikan menjadi selalu (bila frekuensi konsumsi pangan/jajan $7 \mathrm{kali} /$ minggu), sering (4-6 kali/minggu), jarang (<4 kali/minggu), dan tidak pernah. Tingkat kecukupan energi dan zat gizi dihitung dengan membandingkan asupan energi dan protein individu dengan Angka Kecukupan Gizi (AKG) yang dianjurkan per orang per hari. Selanjutnya Tingkat Kecukupan (TK) energi dan protein dikategorikan defisit tingkat berat apabila TK<70\%, defisit tingkat sedang apabila TK 70-79\%, defisit tingkat ringan apabila TK 80-89\%, normal apabila TK 90-119\%, dan lebih apabila $T K \geq 120 \%$. Berbeda dengan energi dan protein, tingkat kecukupan vitamin dan mineral dikategorikan sebagai kurang apabila TK<77\% dan cukup apabila $\mathrm{TK} \geq 77 \%$.

Aktivitas fisik didapatkan dari hasil wawancara langsung dan hasilnya diolah dengan cara mengalikan bobot nilai aktivitas dengan lamanya waktu yang digunakan untuk beraktivitas sehingga didapatkan nilai Physical Activity Ratio (PAR). Akumulasi nilai PAR dari beragam aktivitas fisik yang dilakukan seseorang dalam 24 jam dinyatakan dalam PAL (Physical Activity Level) atau tingkat aktivitas fisik. Selanjutnya PAL akan dikategorikan menjadi empat kategori menurut FAO/WHO/UNU (2001), yaitu aktivitas sangat ringan (jika nilai $\mathrm{PAL}<1.40$ ), aktivitas ringan (jika nilai PAL 1.40-1.69), aktivitas sedang (jika nilai PAL 1.70-1.99), dan aktivitas berat (jika nilai PAL 2.00-2.40).

Penilaian daya ingat sesaat dilakukan dengan menghitung persentase jawaban yang benar dari enam buah kata yang ditampilkan tanpa memperhatikan ejaan dan urutan. Nilai maksimal adalah 100 
dan nilai minimal adalah 0 . Skor daya ingat dikategorikan menjadi “kurang" dan "baik". Daya ingat sesaat dikatakan baik apabila skor daya ingat sesaat pagi dan siang hari di atas 80 . Pertimbangan digunakan batas nilai 80 adalah pendekatan batas nilai skor pengetahuan menurut Khomsan (2000).

Analisis korelasi Pearson dan Spearman digunakan untuk menganalisis hubungan faktor sosial ekonomi, status anemia dan status gizi dengan daya ingat sesaat, sedangkan uji t digunakan untuk menganalisis perbedaan karakteristik sosial ekonomi keluarga antar siswa berdasarkan daya ingat sesaat. Regresi linear digunakan untuk menganalisis pengaruh dari karakteristik subjek, aktivitas fisik, asupan gizi, status anemia, dan status gizi terhadap daya ingat sesaat.

\section{HASIL DAN PEMBAHASAN}

\section{Daya Ingat Sesaat}

Secara keseluruhan, rata-rata skor daya ingat subjek pada pagi hari sebesar 77.3 \pm 13.8 (nilai maksimum $=100$, nilai minimum $=50$ ), sedangkan daya ingat subjek pada siang hari menurun menjadi $71.4 \pm 17.0$ (nilai maksimum=100, nilai minimum=33.3). Hasil uji beda menunjukkan adanya perbedaan signifikan antara daya ingat subjek pada pagi dan siang hari $(\mathrm{p}<0.1)$. Terdapat $46.2 \%$ siswa yang tergolong ke dalam daya ingat kurang dan $53.8 \%$ siswa yang tergolong ke dalam daya ingat baik (Tabel 1).

Tabel 1. Sebaran Siswa berdasarkan Kategori Daya Ingat Sesaat (DIS)

\begin{tabular}{lcccc}
\hline \multirow{2}{*}{ Kategori DIS } & \multicolumn{2}{c}{ Pagi Hari } & \multicolumn{2}{c}{ Siang Hari } \\
\cline { 2 - 5 } & $\mathbf{n}$ & $\%$ & $\mathbf{n}$ & $\%$ \\
\hline Kurang & 18 & 46.2 & 21 & 53.8 \\
Baik & 21 & 53.8 & 18 & 46.2 \\
Total & 39 & 100.0 & 39 & 100.0 \\
\hline Rata-rata skor & $77.3 \pm 13.8$ & \multicolumn{2}{c}{$71.4 \pm 17.0$} \\
\hline
\end{tabular}

\section{Karakteristik Siswa dan Keluarga}

Sebagian besar siswa dengan daya ingat sesaat kurang berusia 10-11 tahun. Rata-rata usia subjek pada kelompok daya ingat sesaat kurang yaitu $10.5 \pm 1.1$ tahun. Sebagian besar siswa dengan daya ingat sesaat baik berusia 9-10 tahun. Ratarata usia subjek pada kelompok daya ingat sesaat baik tidak berbeda jauh, yaitu $10.1 \pm 1.1$ tahun. Hasil uji beda menunjukkan tidak ada perbedaan signifikan rata-rata usia subjek antara kedua kelompok ( $p>0.1)$. Sebagian besar siswa (55.6\%) pada kelompok daya ingat sesaat kurang berjenis kelamin lakilaki. Sebagian besar siswa (66.7\%) pada kelompok daya ingat sesaat baik berjenis kelamin perempuan. Skor daya ingat sesaat siswa perempuan cenderung lebih tinggi $(79.9 \pm 12.8)$ dibandingkan dengan skor daya ingat sesaat siswa laki-laki $(74.0 \pm 14.7)$. Berdasarkan hasil uji beda, tidak ada perbedaan signifikan antara skor daya ingat sesaat laki-laki dan perempuan $(p>0.1)$. Sebaran karakteristik siswa berdasarkan kategori daya ingat sesaat disajikan pada Tabel 2.

Keadaan sosial ekonomi keluarga mencerminkan beberapa proses penting yang memengaruhi perkembangan kognitif dan emosional anak (Shanks et al. 2010). Sebagian besar subjek pada kedua kelompok tergolong ke dalam kategori keluarga sedang dengan rata-rata jumlah anggota keluarga $6 \pm 1.2$ orang. Sebagian besar pendidikan orang tua subjek pada kedua kelompok adalah Sekolah Dasar (SD). Pada pendidikan ayah, terdapat $9.5 \%$ ayah dari subjek yang berdaya ingat baik memiliki pendidikan terakhir Sekolah Menengah Pertama (SMP). Hasil uji beda tidak menunjukkan adanya perbedaan signifikan besar keluarga serta pendidikan ibu subjek antara kedua kelompok $(p>0.1)$. Namun terdapat perbedaan signifikan pendidikan ayah antara kedua kelompok $(p<0.1)$. Sebagian besar ayah subjek pada kedua kelompok bekerja sebagai buruh dan sebagian besar ibu subjek adalah ibu rumah tangga. Menurut

Tabel 2. Sebaran Karakteristik Siswa

\begin{tabular}{|c|c|c|c|c|c|c|c|c|}
\hline \multirow{2}{*}{\multicolumn{2}{|c|}{ Karakteristik Subjek }} & \multicolumn{2}{|c|}{ DIS Kurang } & \multicolumn{2}{|c|}{ DIS Baik } & \multicolumn{2}{|c|}{ Total } & \multirow{2}{*}{ Sig. } \\
\hline & & $n=18$ & $\%$ & $n=18$ & $\%$ & $n=39$ & $\%$ & \\
\hline \multirow{2}{*}{ Jenis Kelamin } & Laki-laki & 10 & 55.6 & 7 & 33.3 & 17 & 43.6 & \multirow{2}{*}{0.197} \\
\hline & Perempuan & 8 & 44.4 & 14 & 66.7 & 22 & 56.4 & \\
\hline \multirow{4}{*}{ Usia (tahun) } & 9 & 4 & 22.2 & 7 & 33.3 & 11 & 28.2 & \multirow{4}{*}{0.311} \\
\hline & 10 & 5 & 27.8 & 7 & 33.3 & 12 & 30.8 & \\
\hline & 11 & 5 & 27.8 & 4 & 19.1 & 9 & 23.1 & \\
\hline & 12 & 4 & 22.2 & 3 & 14.3 & 7 & 17.9 & \\
\hline \multicolumn{2}{|c|}{ Rata-rata usia (tahun) } & \multicolumn{2}{|c|}{$10.5 \pm 1.1$} & \multicolumn{2}{|c|}{$10.1 \pm 1.1$} & & & \\
\hline
\end{tabular}


Orr (2003), pendapatan keluarga memiliki hubungan yang positif dengan prestasi anak. Hal tersebut sejalan dengan penelitian ini, dimana rata-rata pendapatan pada kelompok daya ingat baik, yaitu

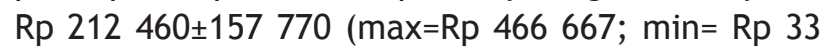
333) sedikit lebih besar dibandingkan dengan ratarata pendapatan subjek pada kelompok daya ingat kurang, yaitu Rp 163 030 144522 (max=Rp 750 000; $\min =\mathrm{Rp} 28$ 571). Meskipun demikian, hasil uji beda tidak menunjukkan perbedaan signifikan pekerjaan orang tua dan pendapatan per kapita antara kedua kelompok $(p>0.1)$. Sebaran karakteristik keluarga siswa dapat dilihat pada Tabel 4.

\section{Pengetahuan Gizi}

Pada kelompok subjek dengan daya ingat kurang, sebagian besar (61.1\%) subjek memiliki pengetahuan gizi yang kurang. Pada kelompok subjek dengan daya ingat baik, sebagian besar (61.9\%) subjek memiliki pengetahuan gizi sedang. Berdasarkan hasil uji, terdapat perbedaan signifikan pengetahuan gizi antara kedua kelompok $(p<0.1)$. Semakin tinggi tingkat pengetahuan gizi seseorang diharapkan semakin baik pula keadaan gizinya sehingga berpengaruh semakin baik pada daya ingatnya. Sebaran siswa berdasarkan pengetahuan gizi disajikan pada Tabel 3.

Tabel 3. Sebaran Siswa berdasarkan Pengetahuan Gizi

\begin{tabular}{lccccc}
\hline Pengetahuan & \multicolumn{2}{c}{ DIS Kurang } & \multicolumn{2}{c}{ DIS Baik } & \multirow{2}{*}{ Sig. } \\
\cline { 2 - 5 } \multicolumn{1}{c}{ Gizi } & $\mathrm{n}=\mathbf{1 8}$ & $\%$ & $\mathrm{n}=\mathbf{2 1}$ & $\%$ & \\
\hline Kurang & 11 & 61.1 & 7 & 33.3 & \\
Sedang & 7 & 38.9 & 13 & 61.9 & 0.067 \\
Baik & 0 & 0.0 & 1 & 4.8 & \\
\hline
\end{tabular}

\section{Konsumsi Pangan}

Sebagian besar subjek (64.1\%) makan sebanyak tiga kali dalam sehari. Sebanyak $53.8 \%$ subjek jarang mengonsumsi sayuran hijau. Sebanyak $66.7 \%$ subjek tidak pernah mengonsumsi daging merah dalam seminggu. Sebagian besar subjek jarang mengonsumsi daging putih (43.6\%), telur (51.3\%), ikan segar (71.8\%), dan protein nabati (53.8\%).

Sebanyak $53.8 \%$ subjek dengan daya ingat baik mengaku selalu jajan, sedangkan $44.4 \%$ subjek dengan daya ingat kurang mengaku jarang jajan. Hasil uji beda menunjukkan perbedaan signifikan kebiasaan jajan subjek antara kedua kelompok $(p<0.1)$.

Berdasarkan tingkat kecukupan gizi, sebagian besar subjek tergolong ke dalam defisit energi tingkat berat. Asupan energi rata-rata kelompok daya ingat kurang yaitu $1084 \pm 302 \mathrm{kkal}$, sedangkan asupan energi rata-rata kelompok daya ingat baik, yaitu $1104 \pm 189$ kkal. Jumlah asupan protein subjek cukup bervariasi, namun hanya $11.1 \%$ dari kelompok daya ingat kurang serta $23.8 \%$ dari kelompok daya ingat baik yang cukup mengonsumsi protein. Asupan protein rata-rata kelompok daya ingat kurang yaitu $33.5 \pm 9.9 \mathrm{~g}$, sedangkan asupan protein ratarata kelompok daya ingat baik tidak jauh berbeda yaitu $32.9 \pm 6.9 \mathrm{~g}$. Hasil uji beda tidak menunjukkan adanya perbedaan yang signifikan asupan energi dan protein antara kedua kelompok $(p>0.1)$.

Hasil penelititan Bryan et al. (2002) menunjukkan bahwa terdapat pengaruh positif dari suplemen vitamin B12, vitamin B6, dan folat terhadap kemampuan memori yang diukur melalui kecepatan pemrosesan, kemampuan mengingat dan mengenal, serta kemampuan verbal. Sebagian besar subjek mengalami defisiensi folat $(95.2 \%)$, vitamin B12

Tabel 4. Sebaran Karakteristik Keluarga

\begin{tabular}{|c|c|c|c|c|c|c|}
\hline \multirow{2}{*}{ Karakteristik Keluarga } & \multirow{2}{*}{ Kategori } & \multicolumn{2}{|c|}{ DIS Kurang } & \multicolumn{2}{|c|}{ DIS Baik } & \multirow{2}{*}{ Sig. } \\
\hline & & $\mathrm{n}=18$ & $\%$ & $\mathrm{n}=\mathbf{2 1}$ & $\%$ & \\
\hline \multirow{3}{*}{ Besar keluarga } & Keluarga kecil & 2 & 11.1 & 3 & 14.3 & \multirow{3}{*}{0.985} \\
\hline & Keluarga sedang & 14 & 77.8 & 16 & 76.2 & \\
\hline & Keluarga besar & 2 & 11.1 & 2 & 9.5 & \\
\hline \multirow{3}{*}{ Pendidikan ayah } & Tidak sekolah & 2 & 11.1 & 0 & 0.0 & \multirow{3}{*}{0.048} \\
\hline & SD & 16 & 88.9 & 19 & 90.5 & \\
\hline & SMP & 0 & 0.0 & 2 & 9.5 & \\
\hline \multirow{3}{*}{ Pendidikan ibu } & Tidak sekolah & 4 & 22.2 & 1 & 4.8 & \multirow{3}{*}{0.341} \\
\hline & SD & 13 & 72.2 & 20 & 95.2 & \\
\hline & SMP & 1 & 5.6 & 0 & 0.0 & \\
\hline \multirow{4}{*}{ Pekerjaan ayah } & Tidak bekerja & 2 & 11.1 & 2 & 9.5 & \multirow{4}{*}{0.742} \\
\hline & Petani, petani ikan & 0 & 0.0 & 1 & 4.8 & \\
\hline & Buruh & 15 & 83.3 & 18 & 85.7 & \\
\hline & Wirausaha, dagang & 1 & 5.6 & 0 & 0.0 & \\
\hline \multirow{2}{*}{ Pekerjaan ibu } & Tidak bekerja & 9 & 50 & 14 & 66.7 & \multirow{2}{*}{0.307} \\
\hline & Petani, petani ikan & 9 & 50 & 7 & 33.3 & \\
\hline \multirow{2}{*}{ Pendapatan per kapita } & $<$ Rp 209777 & 13 & 72.2 & 12 & 57.1 & \multirow{2}{*}{0.652} \\
\hline & $\geq \operatorname{Rp} 209777$ & 5 & 27.8 & 9 & 42.9 & \\
\hline \multicolumn{2}{|c|}{ Rata-rata pendapatan per kapita (Rp) } & 163 & 522 & \multicolumn{2}{|c|}{$212460 \pm 157770$} & \\
\hline
\end{tabular}


(71.4\%), zat besi (95.2\%), dan seng (100\%). Dengan demikian, kecil kemungkinan asupan folat, vitamin B12, zat besi, ataupun seng pada subjek dalam penelitian ini memengaruhi dan meningkatkan daya ingat. Hasil uji beda tidak menunjukkan adanya perbedaan asupan folat, vitamin B12, zat besi, dan seng antara kedua kelompok $(p>0.1)$.

\section{Aktivitas Fisik}

Aktivitas fisik pada kelompok daya ingat kurang sebagian besar tergolong ringan dan sangat ringan. Aktivitas kelompok daya ingat baik sebagian besar tergolong sangat ringan (52.4\%). Hasil uji beda tidak menunjukkan adanya perbedaan aktivitas fisik antara kedua kelompok ( $p>0.1)$. Sebaran siswa berdasarkan aktivitas fisik disajikan pada Tabel 5 .

Tabel 5. Sebaran Siswa berdasarkan Aktivitas Fisik

\begin{tabular}{lccccc}
\hline \multicolumn{1}{c}{ Aktivitas } & \multicolumn{2}{c}{ DIS Kurang } & \multicolumn{2}{c}{ DIS Baik } & \multirow{2}{*}{ Sig. } \\
\cline { 2 - 5 } & $\mathbf{n}$ & $\%$ & $\mathrm{n}$ & $\%$ & \\
\hline Sangat ringan & 8 & 44.4 & 11 & 52.4 & \\
Ringan & 8 & 44.4 & 8 & 38.1 & 0.843 \\
Sedang & 2 & 11.1 & 1 & 4.8 & \\
Berat & 0 & 0.0 & 1 & 4.8 & \\
\hline Total & $\mathbf{1 8}$ & $\mathbf{1 0 0 . 0}$ & $\mathbf{2 1}$ & $\mathbf{1 0 0 . 0}$ & \\
\hline
\end{tabular}

\section{Status Gizi dan Status Anemia}

Berdasarkan status gizi, sebanyak $66.7 \%$ subjek dari kelompok daya ingat kurang serta $85.7 \%$ subjek dari kelompok daya ingat baik memiliki status gizi normal. Penurunan daya ingat siang hari pada subjek dengan status gizi normal cenderung lebih rendah dibandingkan dengan subjek yang tergolong kurus. Terjadi penurunan daya ingat siang hari yang lebih besar pada subjek dengan status gizi sangat kurus.

Berdasarkan status anemia, sebanyak 55.6\% subjek dari kelompok daya ingat kurang serta $76.2 \%$ subjek dari kelompok daya ingat baik tergolong anemia. Penurunan daya ingat pada subjek dengan

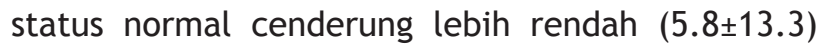
daripada subjek yang mengalami anemia (6.1 \pm 14.2$)$. Rendahnya kemampuan mengingat pada subjek anemia dapat disebabkan oleh rendahnya kadar zat besi di bagian otak tertentu. Rendahnya kadar zat besi di otak dapat mengubah fungsi neurotransmitter, memperlambat proses mielinasi yang berperan dalam fungsi kognitif, sosioemosional, dan motorik (Lozoff et al. 2000). Selain itu, kadar Hb yang rendah pada kelompok anemia menjadikan oksigen yang diangkut oleh $\mathrm{Hb}$ juga menjadi berkurang dari kondisi normal. Keterbatasan oksigen pada otak jelas akan memengaruhi proses berpikir siswa sehingga daya ingat akan menjadi menurun. Sebaran siswa berdasarkan status gizi dan status anemia disajikan pada Tabel 6, sedangkan rata-rata skor daya ingat sesaat pagi, siang, dan penurunan $(\Delta)$ daya ingat sesaat berdasarkan status gizi dan status anemia disajikan pada Tabel 7.

Tabel 6. Sebaran siswa berdasarkan Status Gizi dan Status Anemia

\begin{tabular}{clccccc}
\hline \multirow{2}{*}{ Variabel } & \multirow{2}{*}{ Kategori } & \multicolumn{2}{c}{ DIS Kurang } & \multicolumn{2}{c}{ DIS Baik } & \multirow{2}{*}{ Sig. } \\
\cline { 3 - 6 } & & $\mathrm{n}=18$ & $\%$ & $\mathrm{n}=\mathbf{2 1}$ & $\%$ & \\
\hline \multirow{2}{*}{ Status } & Sangat kurus & 1 & 5.6 & 0 & 0.0 & \\
Gizi & Kurus & 5 & 27.8 & 3 & 14.3 & 0.126 \\
& Normal & 12 & 66.7 & 18 & 85.7 & \\
Status & Normal & 8 & 44.4 & 5 & 23.8 & \multirow{2}{*}{0.182} \\
Anemia & Anemia & 10 & 55.6 & 16 & 76.2 & \\
\hline
\end{tabular}

Tabel 7. Rata-Rata Skor Daya Ingat Sesaat Pagi, Siang, dan Penurunan $(\Delta)$ Daya Ingat Sesaat berdasarkan Status Gizi dan Status Anemia

\begin{tabular}{lccc}
\hline \multicolumn{1}{c}{ Status Gizi } & DIS Pagi & DIS Siang & $\Delta$ DIS \\
\hline Normal & $77.5 \pm 14.0$ & $73.9 \pm 15.9$ & $3.6 \pm 11.7$ \\
Kurus & $79.2 \pm 12.6$ & $65.6 \pm 18.1$ & $13.5 \pm 18.9$ \\
Sangat kurus & 58.3 & 41.6 & 16.7 \\
\hline Status anemia & & & \\
\hline Anemia & $80.1 \pm 13.4$ & $74.0 \pm 16.0$ & $6.1 \pm 14.2$ \\
Normal & $71.8 \pm 13.4$ & $66.0 \pm 18.1$ & $5.8 \pm 13.3$ \\
\hline
\end{tabular}

Faktor-faktor yang Berhubungan dengan Daya Ingat Sesaat

Hasil uji korelasi menunjukkan adanya korelasi positif antara daya ingat pada siang hari dengan status gizi subjek $(p<0.1)$. Artinya semakin baik status gizi maka semakin baik pula daya ingat pada siang hari. Menurut Jukes (2002), anak yang terinfeksi cacing dan memiliki status gizi yang buruk rentan mengalami penurunan fungsi kognitif.

Anemia merupakan kondisi kurang darah yang terjadi bila kadar hemoglobin darah kurang dari normal (Depkes 2007). Kurangnya kadar hemoglobin dapat menurunkan konsentrasi karena kurangnya oksigen yang dibawa ke otak. Hasil uji korelasi menunjukkan adanya korelasi negatif antara daya ingat pagi hari dengan status anemia $(p<0.1)$. Akan tetapi, tidak ada korelasi yang signifikan antara daya ingat siang dengan status anemia, serta penurunan daya ingat dengan status anemia $(p>0.1)$. Kondisi daya ingat pagi hari tersebut sejalan dengan penelitian Sungthong et al. (2002) yang menunjukkan bahwa anak-anak yang mengalami anemia defisiensi besi mempunyai fungsi kognitif yang rendah dibandingkan dengan anak-anak yang tidak anemia dan terjadi peningkatan fungsi kognitif sejalan dengan 
peningkatan kadar hemoglobin. Selain status gizi dan status anemia, pengetahuan gizi juga berhubungan dengan daya ingat. Tingkat pengetahuan gizi seseorang berpengaruh terhadap sikap dan perilaku dalam pemilihan makanan yang pada akhirnya akan berpengaruh pada keadaan gizi individu yang bersangkutan. Semakin tinggi tingkat pengetahuan gizi seseorang diharapkan semakin baik pula keadaan gizinya. Hasil uji korelasi menunjukkan adanya hubungan yang signifikan antara daya ingat pagi dan siang hari dengan pengetahuan gizi $(p<0.1)$.

Hasil analisis regresi linier berganda antara skor daya ingat sesaat siang dengan status gizi dan pengetahuan gizi menunjukkan bahwa status gizi dan pengetahuan gizi berpengaruh sebesar $19.7 \%$ terhadap daya ingat sesaat siang. Persamaan regresi linier berganda untuk skor daya ingat sesaat siang yaitu:

\section{Skor daya ingat siang $=56.350+4.464$ status gizi+0.347 pengetahuan gizi}

Status gizi berpengaruh signifikan terhadap daya ingat sesaat siang pada $p<0.1$. Hal ini menunjukkan bahwa semakin baik status gizi, maka penurunan daya ingat sesaat juga semakin kecil. Pengetahuan gizi berpengaruh signifikan terhadap daya ingat sesaat siang $(p<0.1)$. Hal ini menunjukkan bahwa semakin baik pengetahuan gizi, maka semakin baik pula daya ingat sesaat pada siang hari.

\section{KESIMPULAN}

Berdasarkan skor daya ingat sesaat pada pagi hari, terdapat $46.2 \%$ subjek yang tergolong ke dalam daya ingat kurang dan 53.8\% subjek tergolong ke dalam daya ingat baik. Perbedaan signifikan terlihat pada pendidikan ayah, pengetahuan gizi, dan kebiasaan jajan subjek, antara subjek yang memiliki daya ingat kurang dan subjek yang memiliki daya ingat baik. Faktor-faktor yang berhubungan dengan daya ingat sesaat pagi yaitu pengetahuan gizi dan status anemia, sedangkan faktor-faktor yang berhubungan dengan daya ingat sesaat siang hari yaitu pengetahuan gizi dan status gizi. Faktor-faktor yang memengaruhi daya ingat sesaat dalam penelitian ini yaitu pengetahuan gizi, status gizi, dan status anemia, semakin baik skor pengetahuan gizi dan status gizi, maka semakin baik pula skor daya ingat sesaat.

Daya ingat sesaat sebaiknya lebih diperhatikan karena pada penelitian ini masih terdapat $46.2 \%$ subjek yang memiliki daya ingat sesaat kurang. Pe- ningkatan daya ingat dapat dilakukan dengan berbagai cara, salah satunya dengan meningkatkan status gizi. Subjek yang memiliki status gizi baik memiliki daya ingat sesaat yang lebih baik. Selain itu, sebaiknya subjek didorong untuk terbiasa sarapan agar kemampuan mengingat pada pagi hari lebih optimal. Saran bagi penelitian selanjutnya yaitu sebaiknya penelitian dilakukan dengan jumlah subjek yang lebih besar agar hubungan antar variabel lebih bermakna.

\section{DAFTAR PUSTAKA}

Bryan J, Calvaresi E, \& Hughes D. 2002. Short-term folate, vitamin B-12 or vitamin B-6 supplementation affects memory performance but not mood in women of various ages. Journal of Nutrition, 132, 1345-1356.

[Depkes] Departemen Kesehatan. 2007. Laporan Hasil Riset Kesehatan Dasar Indonesia. Badan Penelitian dan Pengembangan Kesehatan, Departemen Kesehatan RI, Jakarta.

[FAO]. 2001. Human Vitamin and Mineral Requirement (report of a joint FAO/WHO expert consultation Bangkok, Thailand). Food and Nutrition Division, Rome.

Jukes M. 2002. Heavy schistosomiasis associated with poor short-term memory and slower reaction times in Tanzanian school children. Tropical Medicine and International Health, 7(2), 104-117.

Khomsan A. 2000. Metode Pengukuran Pengetahuan Gizi. Jurusan Gizi Masyarakat dan Sumber Daya Keluarga, Fakultas Pertanian, Institut Pertanian Bogor, Bogor.

Kustiyah et al. 2006. Pengaruh intervensi makanan kudapan terhadap peningkatan kadar glukosa darah dan daya ingat anak sekolah dasar. Media Gizi dan Keluarga, 30(1), 42-57.

Lozoff et al. 2000. Poorer behavioural and developmental outcome more than 10 years after treatment for iron deficiency in infancy. Pediatrics, 105(4),1-11.

Mc Gregor SG \& Ani C. 2001. A review of studies on the effect of iron deficiency on cognitive development in children. Journal of Nutrition, $131,649 \mathrm{~s}-668 \mathrm{~s}$.

Morris MS, Jacques PF, Rosenberg IH, \& Selhub J. 2007. Folate and vitamin B12 status in relation to anemia, macrocytosis, and cognitive impairment in older Americans in the age of folic acid fortification. American Journal of Clinical Nutrition, 85(1),193-200. 
Orr A. 2003. Black-White differences in achievement: the important of wealth. Sociology of education, 76(4), 281-304.

Pollit E. 2000. Developmental sequel from early nutritional deficiencies: Clonclusive and probability judgements. Journal of Nutrition, 130,350s-353s.

Shanks TRW, Kim Y, Loke V, \& Destin M. 2010. Assets and child well-being in developed countries.
Children and Youth Services Review, 32,14881496.

Sungthong R, Mo-suwan L, Chongsuvivatong V. 2002. Effects of haemoglobin and serum ferritin on cognitive function in school children. Asia Pacific Journal of Clinical Nutrition, 11(2), 117-122. 